EFFECT OF MARKET ORIENTATION, NETWORK CAPABILITY AND

ENTREPRENEURIAL ORIENTATION ON INTERNATIONAL

PERFORMANCE OF SMALL AND MEDIUM ENTERPRISES (SMES)

\title{
HIGHLIGHTS
}

- International Entrepreneurial Orientation and Network Capability positively influence SMEs International Performance

- International Market Orientation does not influence SMEs International Performance

- International Entrepreneurial Orientation directly influences International Market Orientation and Network Capability

- There exist interrelations between strategic orientations and other strategic factors that determine SMEs International Performance 


\section{EFFECT OF MARKET ORIENTATION, NETWORK CAPABILITY AND \\ ENTREPRENEURIAL ORIENTATION ON INTERNATIONAL \\ PERFORMANCE OF SMALL AND MEDIUM ENTERPRISES (SMES)}

Solano Acosta, Alexandra ${ }^{\mathrm{a}}$

Herrero Crespo, Ángel ${ }^{\mathrm{b}}$ (Corresponding author)

Collado Agudo, Jesús ${ }^{\mathrm{c}}$

a Departamento de Economía y Negocios Internacionales, Tecnológico de Monterrey -

Campus Ciudad de México, Mexico City, Mexico, Calle del Puente 222, Ejidos de

Huipulco, 14380 Tlalpan. Email: asolano@itesm.mx. Tel. +55 54832244.

b Department of Business Administration, Universidad de Cantabria, Santander, España. Av. Los Castros, s/n - 39005. Email: herreroa@unican.es. Tel. +34 942203908.

${ }^{\mathrm{c}}$ Department of Business Administration, Universidad de Cantabria, Santander, España. Av. Los Castros, s/n - 39005. Email: colladoj@unican.es. Tel. +34 942203923.

Acknowledgement: We would like to thank Fedex and the Mexican Department of Economy for their help in the survey and field work. 


\title{
EFFECT OF MARKET ORIENTATION, NETWORK CAPABILITY AND \\ ENTREPRENEURIAL ORIENTATION ON INTERNATIONAL \\ PERFORMANCE OF SMALL AND MEDIUM ENTERPRISES (SMES)
}

\begin{abstract}
This study contributes to literature on the internationalization of SMEs by analysing the influence of International Market Orientation, Network Capability, and International Entrepreneurial Orientation on the International Performance of this kind of businesses. Particularly, both the direct effects of explanatory variables of International Performance and interdependence relations between them are analysed. Results obtained from a sample of 161 Mexican SMEs using SEM-PLS analysis show that the International Performance of this kind of businesses is favourably influenced by their Network Capability and International Entrepreneurial Orientation, but not by their International Market Orientation. Similarly, it is verified that interdependence relations exist among the explanatory variables of International Performance of SMEs, where positive impact of International Entrepreneurial Orientation is observed on Network Capability and the International Market Orientation of SMEs.
\end{abstract}

Keywords: SMEs, Performance, Market Orientation, Network Capability, Entrepreneurial Orientation. 


\section{INTRODUCTION}

Small and medium enterprises (SMEs) have become ever more important actors in the international trading sphere (Knight and Cavusgil 2005; Rialp et al. 2005; Torres et al. 2015). Globalization processes such as advancements in technology, communications and transportation have softened trade barriers and generated changes in the global value chains, resulting in a growing number of businesses that expand their activities internationally (Covin and Miller 2014). Consequently, various authors have stated the need of researching the internationalization process for SMEs (Musteen et al. 2014), especially taking into account the specific characteristics of this kind of businesses (Ripollés et al. 20012; Laufs and Schwens, 2014). In this context, and according to the approach suggested by Ferreira et al. (2016), this research intends to analyse the influence of strategic variables on the International Performance of SMEs, integrating the approaches of two main theories: Strategic Management Theory and Dynamic Capabilities Theory. More specifically, the objective of this study is to examine how strategic orientations and the firm's networking capability, which have been identified as dynamic capabilities in previous literature, influence SMEs performance in international markets, and which are the interrelations between these strategic variables determining international performance.

Regarding strategic orientations, we focus on Market Orientation and Entrepreneurial Orientation, which has been identified as the most relevant strategic orientations in recent literature (Hakala 2011; Deutscher et al. 2016; Pehrsson 2016; Mu et al. 2017), and which are also considered as dynamic capabilities of special relevance for International Performance of SMEs (Knight and Liesch 2016). Additionally, following 
the conceptual model proposed by Weerawardena et al. (2007) and Mu et al. (2017) this research also examines the effect exerted by Network Capability (conceived as a dynamic capability with strategic scope) in combination with these strategic orientations.

Recent literature has highlighted the scarce research available with regard to the role of strategic orientations and postures in the internationalization process of SMEs. In this sense, Hagen et al. (2017, pp. 1) state that "although findings in all streams concur to the view that the firms' strategic posture is crucial to survive and prosper in a domestic competitive environment only little research informs about its role in determining the international strategic behavior and performance" and "this is even more true for SMEs”. Similarly, taking as a basis the postulates of Hakala (2011), Paul et al. (2017, pp. 337) point out the need to develop a theoretical setting on "configuring and understanding the SMEs strategic orientation towards exports". Moreover, Laufs and Schwens (2014) establish that the influence of strategic orientations on SMEs' internationalization could be influenced by the particularities of these type of firms, so specific research in the field of SMEs is needed. However, according to Paul et al. (2017) much of the study of international entrepreneurship has focused on International New Ventures (INVs) and 'Born Globals', so there is still scope for research on the factors determining the internationalization of SMEs in general, without specifically focusing on companies with international focus from inception.

Laukkanen et al. (2013) highlight that although most studies on the effect of strategic orientations on SMEs performance have mainly focussed on single orientations at any given time, SMEs have better results if they build their strategies on multiple strategic orientations. Similarly, Paul et al. (2017, pp. 337) point out that "there are further possibilities to develop frameworks, models, and theories" combining different strategic 
orientations to analyse their effect on SMEs export performance. This study intends to cover this gap in the literature by proposing an integrative model of the International Performance of SMEs, which includes two of the most relevant strategic orientations studied in previous literature (and that are also defined as dynamic capabilities): Market Orientation and Entrepreneurial Orientation (Hakala 2011; Deutscher et al. 2016; Pehrsson 2016; Mu et al. 2017). On the one hand, Market Orientation has been identified in prior literature as a direct determinant of International Performance for large and medium enterprises (Cadogan et al. 2003; Chung 2012; Boso et al. 2013), yet the empirical evidence available in the sphere of SMEs is still limited (Armario et al. 2008; Zhou et al. 2010; Ripollés et al. 2012; Torres et al. 2015). On the other hand, the search for business opportunities in new markets constitutes a form of corporate entrepreneurship, for which several investigations have analysed the effect of Entrepreneurial Orientation on International Performance (Hagen et al. 2012; EscandónBarbosa 2016). Notwithstanding, studies focused on SMEs are scarce and as yet inconclusive.

Additionally, recent research has also highlighted the need to obtain additional evidence on the influence of Network Capability on SMEs' International Performance, in combination with strategic orientations (Knight and Liesch 2016). According to several authors (Moen and Servais 2002; Mort and Weerawardena 2006; Weerawardena et al. 2007; Ripollés et al. 2012), the limitation of resources of SMEs makes it of special importance to have partners when businesses address international markets. Therefore, as stated by Musteen et al. (2014), the capability to set up networks may be a factor of special importance for success in the internationalization of this kind of businesses. However, there is little evidence available that considers together Network Capability and strategic orientations, specifically in the case of SMEs. 
Furthermore, recent literature has highlighted the need to deepen on the research on interdependence between strategic orientations and other explanatory variables of entrepreneurial performance, both at general level (Deutscher 2016) and in the sphere of internationalization (Pehrsson 2016). More specifically, Hakala (2011) postulates a "complementary approach" to the study of strategic orientations, focused on the relationships between orientations and the patterns they form, as an important emerging issue for large and small businesses alike. Similarly, Hagen et al. (2017) point out that more research is needed on the "intricacies between different strategic orientations" of international SMEs as "empirical validation is partial and opens questions more than answering them". In consequence, in addition to analysing the impact of these three factors on the International Performance of SMEs, our research also examines interrelations existing between International Market Orientation, Network Capability, and International Entrepreneurial Orientation.

Therefore, this research provides two main contribution with regard to previous literature. First, we examine jointly the influence on International Performance of SMEs of three strategic factors, which can be conceived as dynamic capabilities (Knight and Leisch 2016): International Market Orientation, Network Capability, and International Entrepreneurial Orientation. Second, following the "complementary approach" proposed by Hakala (2011) we study the interrelations existing between these strategic factors, in order to propose a framework or model of their intricacies and how its combination influences International Performance (Pehrsson 2016; Hagen et al. 2017). Besides, these contributions are especially relevant due to the scarce evidence available on this issue in the specific scope of SMEs (Laufs and Schwens 2014; Knight and Leisch 2016; Paul et al. 2017). 
Hereinafter, after briefly presenting the Strategic Management Theory and the Dyamic Capability Theory as basic conceptual framework of this research, we review the relevant literature on explanatory variables of International Performance, with special attention to available evidence for SMEs, and we propose the appertaining research hypotheses. Next, we detail the methodology followed for measuring variables, the procedure for gathering information, and the characteristics of the SMEs sample used. Afterwards, results obtained by following a PLS Structural Equation Models approach are presented and, lastly, theoretical and practical implications are put forward, including limitations and future lines of research.

\section{REVIEW OF LITERATURE AND RESEARCH HYPOTHESES}

\subsection{Strategic Management Theory and Dynamic Capabilities Theory}

Strategic Management Theory has had a great development during the last decades, due to its relevance for organizational improvement, as it can affect organizational adaptability, performance and legitimacy (Johnsen, 2015). Strategic management is commonly conceptualised as the alignment of internal capabilities with external demands, and this alignment may take the form of plans, patterns, positions, perspectives, and plots (Mintzberg et al., 2009). According to Bryson et al. (2010, p. 497) strategic management "should be understood as partially routinized strategic thinking, acting, and learning behaviors that involve typically complex assemblies of human and nonhuman actors held together by ordering and sensemaking principles that are maintained and changed over time through the way they are performed."

Thus, since its original formalization in the 1960s, the Strategic Management Theory has become an increasingly complex and diverse field (Johnsen, 2015; Ferreiro, 2016), 
which integrates different schools of thought. In particular, Mintzberg et al. (2009) identify three normative schools (the design, planning and positioning school), six descriptive schools (the entrepreneurial, cognitive, learning, power, culture, and environmental school) and one mixed (configuration) school. Yadav et al. (2014) consider six main frameworks within Strategic Management Theory: Theory of Strategy and Structure (Chandler, 1962), Industrial Organization View (Porter, 1980); Resource Based View (Wernerfelt, 1984; Barney, 1991), Strategic Fit (Chom, 1991), Stakeholder Theory (Freeman, 1984), Contingency Theory (Donaldson, 2001), and Dynamic Capabilities View (Teece et al., 1997; Eisenhardt and Martin, 2000).

On the basis of a deep review of the literature on this topic, Ferreira et al. (2016) point out that "Strategic management (SM) as an academic field of study remains relatively recent (Nerur et al. 2008)", so although it "has attained a certain level of maturity"..." it is commonly asserted that the field of SM is fragmented and lacks a coherent identity (Nag et al. 2007)." Therefore, there is no single discipline covering all aspects of strategy, so that there has been recourse to combinations of diverse fields to generate integrative approaches to the various domains of Strategic Management. In this sense, Ferreira et al. (2016) suggest that future research should focus on the integration of the diverse strategic approaches and studying their implications for attaining particular levels of performance, with special attention to emerging theoretical frameworks such as strategic entrepreneurship and dynamic capabilities.

Consistent with this approach, Teece (2014) affirms that while "the field of strategic management has accepted the challenge and valiantly endeavours to uncover the fundamental sources of competitive advantage..., the "dynamic capabilities" approaches grapple with the question and have had a significant impact on mainstream management theory and practice." Accordingly, dynamic capabilities approach has been one of the 
most impacting theoretical framework on strategic management and competition during the last decade (Yadav et al. 2014).

Eisenhardt and Martin (2000, p. 1107) define dynamic capabilities as “...the organizational and strategic routines by which firms achieve new resource configurations as markets emerge, collide, split, evolve and die". Thus, dynamic capabilities are linked with firm performance in that they change the firm's bundle of resources, operational routines and competencies which in turn affect economic performance (Helfat and Raubitschek, 2000; Zollo and Winter, 2002). According to Weerawardena et al. (2007) the dynamic capabilities view, in comparison with the earlier Industrial Organization View (e.g. Porter, 1980) and the resource-based view (RBV) (Wernerfelt, 1984; Barney, 1991), assigns a prominent role to the entrepreneurial decision-makers in the formulation and implementation of competitive strategy. Similarly, Teece (2014) highlights that "whereas traditional economic development theorists stress resource accumulation, the dynamic capabilities framework stresses the importance of enterprise-level entrepreneurship, innovation, learning, and good strategy". In consequence, the Dynamic Capabilities Theory integrates the strategic management with entrepreneurial orientation, which a significant application to diverse and changing contexts as are international markets (Weerawardena et al., 2007; Knight and Liesch, 2016). This research positions within the recent approaches of the Strategic Management Theory and on the Dynamic Capabilities Theory, and adopts an integrative perspective of strategic orientations and dynamic capabilities to explain international performance of SMEs.

\subsection{Market Orientation and International Performance}


Market Orientation has been one of the key concepts in strategy (Balodi 2014; Hagen et al. 2017) and marketing literature (Boso et al. 2013; Escandón-Barbosa et al. 2016) in the last two decades, with two fundamental theoretical approaches for its definition and measurement (Shoham et al. 2005). On one side, Narver and Slater (1990) adopt a cultural perspective and define Market Orientation as "the organization culture that most effectively and efficiently creates the necessary behaviors for the creation of superior value for buyers and, thus, continuous superior performance for the business". In consonance with this approach, these authors propose that Market Orientation features three different dimensions: Customer Orientation, Competitor Orientation, and Inter-functional Coordination. For their part, Kohli and Jaworski (1990) pose a perspective for Market Orientation as a process based on information, and also identify three stages or dimensions: Market Intelligence, based on present and future needs of customers; the process of Dissemination of Information generated within the organization; and Response to the Market. Both approaches make evident the need for considering the needs and wishes of customers and the strategies of competitors in the definition of marketing strategies and policies, but each adopts a different perspective. Most empirical studies confirm a positive relationship between Market Orientation and various measures of Entrepreneurial Performance (Cano et al. 2004; Kirca et al. 2005; Ellis 2006; Laukkanen et al. 2013; Balodi 2014). More specifically, Kirca et al. (2005) conduct a meta-analysis of prior literature on this matter and observe that Market Orientation positively affects different variables linked to the performance of the company, such as business evolution, sales, market shares, perceived quality, customer loyalty and general satisfaction. This evidence supports the logic that a stronger focus on knowing and satisfying customers' needs and demands leads to higher sales and 
profits in the long-term, whereas analysing and anticipating competitors' actions allows protecting and maintaining competitive position in the market.

Conceptually, this rationale should be, at least, as important in international markets as it is in the local market, given that internationalization requires to meet the needs and demands of customers that are less known for the company, and to face competitors that may not be present in other markets or that may have different positions and strategies in a specific foreign market. Therefore, focusing on analysing and responding to customers and competitors in international markets would be a necessary condition for obtaining better levels of performance. However, the empirical evidence available for the effect of Market Orientation on International Performance is very limited, especially in the specific scope of SMEs.

In one of the seminal works in this field, Cadogan et al. (2003) obtain empirical evidence that confirms that company behaviours oriented to the market positively influence their international performance. More recently, Chung (2012) and EscandónBarbosa et al. (2016), highlight that International Market Orientation favourably contributes to the strategic performance of exporting companies. Likewise, Boso et al. (2013) confirm that the companies' International Market Orientation positively influence the performance of their products in export markets. Finally, in one of the very scarce works in the specific scope of SMEs, Armario et al. (2008) support that Market Orientation has a positive effect on performance in foreign markets. According to this evidence and to the theoretical rationale previously established, the following research hypothesis is proposed:

H1: International Market Orientation positively influences the International Performance of SMEs. 


\subsection{Network Capability and International Performance}

Relationships and networks have been the subject of analysis in internationalization literature in recent years, with special attention to small and medium enterprises, given the relevance of overcoming "shortage of resources" required for competing in the international environment (Moen and Servais 2002; Mort and Weerawardena 2006; Weerawardena et al. 2007; Ripollés et al. 20012). In this context, Walter et al. (2006, p. 542) conceive the Network Capability as “firm's abilities to develop and utilize interorganizational relationships to gain access to various resources held by other actors". In the same vein, Gulati (1998) defines the International Network Capability as the ability of a company to obtain resources from the environment through the creation of alliances and social bonds for use in their activities in international markets. Accordingly, Network Capability has been conceived as a dynamic capability, as it allows the firm to identify opportunities and to respond quickly to them (Weerawardena et al. 2007; Knight and Liesch 2016).

Several authors have indicated that the Network Capability is integrated by various dimensions that represent different abilities for the management of relationships with other organizations and partners. In the specific sphere of internationalization, Ritter and Gemünden (2003) and Walter et al. (2006) propose four phases or dimensions for the Network Capability: Coordination, Relational Skills, Partner Knowledge, and Internal Communication. Walter et al. (2006) define Coordination as a structure of common use (permanent or temporary) to bring together groups that are working on a common result. Relational Skills include certain aspects such as the ability to communicate, extroversion, capacities for handling conflict, empathy, emotional stability, self-reflection, sense of justice and cooperativity (Marshall et al. 2003). Partner Knowledge reflects organized and structured information about suppliers, 
customers and competitors (Walter et al. 2006), and allows for the reduction of transaction costs and proactive management in the solution of conflicts. Lastly, Internal Communication includes the assimilation and dissemination of information about partners to all the departments involved (Cohen and Levinthal 1990).

The interrelation between Network Capability and International performance has been established from diverse theoretical approaches, sharing their focus on the fact that the companies' ability to establish and manage relations with partners allows them to obtain competitive advantages that are critical in international markets, especially in the case of SMEs, due to their resource restrictions. Thus, in the Theory of Corporate Networks, internationalization is viewed as an entrepreneurial process contained in an institutional and social network that supports the company in terms of access to information, human capital, finance, and other aspects (Bell et al. 2003). Similarly, several researchers have observed that networks contribute to the success of small and medium export enterprises by helping to identify new market opportunities and contributing to the building of knowledge (Coviello and Munro 1995; Chetty and Holm 2000). From the perspective of Dynamic Capabilities Theory, Weerawardena et al. (2007) pose that the Network Capability is a determining factor for accelerated internationalization of SMEs. For their part, based on the framework of Entrepreneurship Theory, Walter et al. (2006) confirm a positive effect of Network Capability on the International Performance of spin-offs.

According to this evidence, the following research hypothesis is proposed:

H2: Network Capability positively influences the International Performance of SMEs.

\subsection{Entrepreneurial Orientation and International Performance}


The international activity of a company is, in itself, an entrepreneurial act, for it consists in identifying and exploring new business opportunities in new environments and, therefore, requires an innovative and proactive attitude, as well as to assume the additional risk that entails acting in unknown competitive environments where the probability of failure is greater (Zhou et al. 2010). Consequently, various authors have stated the importance of Entrepreneurial Orientation in the internationalization of businesses (Knight 1997; McDougall and Oviatt 2000; Jones and Coviello 2005; Weerawardena et al. 2007), although most of the empirical studies have focused on new businesses (born-globals) and evidence available for companies already established is more limited (Keupp and Gassmann 2009).

Taking as reference the seminal definition of Entrepreneurial Orientation proposed by Miller (1983), several authors have raised and defined the concept of International Entrepreneurial Orientation, which includes the notion of internationalization (McDougall and Oviatt 2000; Knight and Cavusgil 2004; Freeman and Cavusgil 2007; Covin and Miller 2014). Thus, Knight and Cavusgil (2004, p. 129) define International Entrepreneurial Orientation as the one that “(...) reflects the firm's overall innovativeness and proactiveness in the pursuit of international markets. It is associated with innovativeness, managerial vision, and proactive competitive posture". In the same vein, Freeman and Cavusgil (2007, p. 3) pose that this concept "the behavior elements of a global orientation and captures top management's propensity for risk-taking, innovativeness and proactiveness". In this fashion, most investigations of the matter adopt the initial definition of Miller (1983) and analyse this variable as a second order factor integrated by the three original dimensions (Marino and George 2011): Innovativeness, Proactiveness, and Risk-Taking. 
Innovativeness represents "a firm's tendency to engage in and support new ideas, novelty, experimentation, and creative processes that may result in new products, services, or technological processes" (Lumpkin and Dess 1996, p. 152). According to Venkatraman (1989, p. 949), Proactiveness refers to "seeking new opportunities which may or may not be related to the present line of operations, introduction of new products and brands ahead of competition, strategically eliminating operations which are in the mature or declining stages of life cycle". Lastly, Risk-Taking reflects the level of willingness of the administrators to commit company resources when the decision has a considerable probability of failure (Lumpkin and Dess 1996).

In general, the empirical evidence available has supported the positive effect of International Entrepreneurial Orientation on performance in foreign markets. Knight (2000) observed that International Entrepreneurial Orientation is significantly and positively associated with the "international preparation" which, in turn, is positively associated with the company's performance measured subjectively. Dimitratos et al. (2004) confirm a positive effect of International Entrepreneurial Orientation on the satisfaction of executives with results in foreign markets, even though they did not observe a significant effect on objective performance measurements. For their part, Hagen et al. (2012) conversely state that companies with "entrepreneurial growth" strategies show very high levels of International Performance, measured through objective and subjective indexes. Lastly, Escandón-Barbosa et al. (2016) observe that the International Entrepreneurial Orientation is positively associated with International Performance of exporting companies.

According to this evidence, the SMEs' performance in international markets would be better if they are innovative, proactive and prone to take risks, which is consistent with the Dynamic Capabilities Theory. Thus, in international markets characterized by 
customers with specific needs and demands and a different competitive environment, the capability to innovate and be proactive in developing new strategies, accepting reasonable risk, is crucial to compete successfully and obtain better performance in terms of sales and profits. Consistent with this rationale and with the empirical evidence detailed before, the following research hypothesis is proposed:

H3: International Entrepreneurial Orientation positively influences the International Performance of SMEs.

From the perspective of Strategic Management Theory, Hakala et al. (2011) suggest that Entrepreneurial Orientation "underlies and determines the pattern of the other strategic orientations that an organization adopts", such as Market Orientation. Consistent with this approach, in their seminal article, Slater and Narver (1995) suggest that Entrepreneurial Orientation can trigger market-oriented behaviors that enable the firm to identify the innovations or improvements that the end consumer requires, overtake its competitors and assume the risk implicit in these decision (Ripollés et al. 2012). According to this approach, Zahra (2008) states that, while a strong International Entrepreneurial Orientation indicates a corporate culture that facilitates the identification and exploitation of emerging opportunities and, therefore, promotes the development of new products and services (Lumpkin and Dess 1996), the growth of entrepreneurial companies requires them to be oriented to market demands. In the same vein, Zahra and Garvis (2000) observe that the International Entrepreneurial Orientation improves a company's capability to perceive and recognize market opportunities before its rivals, thus obtaining an advantage in customer relations and a larger market share. More recently, Ripollés et al. (2012) have obtained empirical evidence that supports the positive effect of Entrepreneurial Orientation on International Market Orientation. The results obtained in these studies evidence that Market Orientation, conceived as the 
emphasis on meeting customers' demands better than the competition, is superior if the company is innovative and proactive in the development of new strategies and solutions to satisfy customers, and it accepts the risks that this requires. Consequently, the following research hypothesis is proposed:

H4: International Entrepreneurial Orientation positively influences the Market Orientation of internationalizing SMEs.

Corporate network building is one of the primary strategies followed by entrepreneurial companies in order to gain access to resources and protect themselves from uncertainty and obstacles in the sphere of their operations (Steensma et al. 2000). In this regard, Walter et al. (2006) observe that the effect of International Entrepreneurial Orientation on International Performance is greater the higher the Network Capability of the organization. Moreover, the model proposed by Weerawardena et al. (2007) for explaining determinant factors of accelerated internationalization for SMEs states that the International Entrepreneurial Orientation has a positive effect on the Network Capability. For their part, Zhou et al. (2010) have obtained empirical evidence that supports the fact that the Network Capability is favourably influenced by two dimensions of International Entrepreneurial Orientation: Innovativeness and Proactiveness. These studies come to show that the ability to create and manage networks in international markets is higher if the company is innovative and proactive, as this means that it is more receptive to develop new managerial approaches and meet the expectations and requirements of partners, accepting the risks related to these changes. Accordingly, the following research hypothesis is posited:

H5: International Entrepreneurial Orientation positively influences the Network Capability of internationalizing SMEs. 
The proposed research hypotheses give rise to an explanatory model of the effect of International Entrepreneurial Orientation, International Market Orientation, and Network Capability, as represented in Figure 1.

\section{Insert Figure 1 about here}

\section{METHODOLOGY}

In order to provide an answer to the research hypotheses and to compare the proposed model, a quantitative study was developed by means of surveys addressed to managers of export SMEs in Mexico. Hereinafter are detailed the main characteristics of measuring instruments used, as well as the sampling procedure.

\subsection{Measuring instruments}

Information was gathered using a structured questionnaire where a series of multiattributes scales was included with reference to the different variables identified in the proposed model (Appendix I summarizes the items of each measurement scale, as well as the sources from which they are taken). Seven point Likert scales are used, where 1 indicates complete disagreement with the presented statement, and 7 complete agreement. In following the usual approach in internationalization literature, in the present research the dependent variable of International Performance is measured through subjective indexes (Musteen et al. 2014; Escandón-Barbosa et al. 2016). Particularly, and taking as a basis the measurement scale proposed by Knight and Cavusgil (2004), International Performance is conceived as a reflective, second order 
factor that incorporates two dimensions: satisfaction with International Results in relation to initial expectations, and Comparative Performance in relation to the main competitors.

In accordance with the approach of Narver and Slater (1990), International Market Orientation is conceived as a reflective, second order construct, integrated by three dimensions: Customer Orientation, Competitor Orientation, and Inter-functional Coordination. Measuring instruments for each of these constructs are taken from Narver and Slater (1990). For its part, and following the proposal of Ritter and Gemünden (2003) and Walter et al. (2006), the Network Capability is conceived as a reflective, second order factor integrated by four dimensions: Coordination, Relational Skills, Partner Knowledge, and Internal Communication. Lastly, in accordance with the predominant approach of prior literature, International Entrepreneurial Orientation is conceived as a second order construct of reflective nature, integrated by the dimensions of Innovativeness, Proactiveness, and Risk-Taking. In order to measure these constructs, the scale proposed by Zhou et al. (2010) is used, drawing on the presentations by Lumpkin and Dess (1996) and Knight and Cavusgil (2004).

Given that all the measurement instruments used in this research were originally developed in English and that the questionnaire had to be administered in Spanish to managers of export SMEs in Mexico, we used the back translation procedure following the recommendations made by Douglas and Craig (2007) in order to check translation accuracy. First, the researchers (Spanish native-speakers with a good domain of English language) made a direct translation of the scales from English to Spanish, which was then revised and back translated to English by a native proof-editor, to guarantee conceptual equivalence. Additionally, and following the recommendations made by Douglas and Craig (2007), prior to the development of field work, a pre-test was 
conducted with owners and executives from 25 export SMEs located in Mexico City, in order to confirm that all questions were adequately understood by the respondent.

\subsection{Data collection and sampling}

The population subject matter of the present research includes 8,887 export SMEs registered by the National Institute of Statistics and Geography of Mexico (Instituto Nacional de Estadística y Geografía, INEGI). The sampling procedure used is not probabilistic, for we were unable to gain access to the updated census of companies and, therefore, it was not possible to know the probability of any particular element of the population being selected for the sample. Consequently, the convenient sampling procedure was used, where companies were contacted who had participation in the Export SMEs Fedex Tour event, organized by Fedex in coordination with the Mexican Department of Economy. The survey was conducted personally with owners and/or managers from each export SME, using electronic devices (tablets) to facilitate the gathering of information. Lastly, 161 valid surveys were obtained, which implies a sampling error of $7.00 \%$ for a population of 8,887 export SMEs included in the universe of this study (with a reliability level of $95.5 \%$, for the most unfavourable case $\mathrm{p}=\mathrm{q}=0.5$ ).

Table 1 summarizes the main characteristics of the export SMEs sample obtained. $50 \%$ of respondents are owners of the companies and the other half are executives operating within the same. Most of the companies surveyed are exporting goods $(49.9 \%$ of industrial products, and $26.1 \%$ of consumer goods). $70 \%$ of the sample invoices less than 10 million euros a year, and $64 \%$ of the sample exports at least $25 \%$ of their total sales. $46.6 \%$ made their first export before the first three years of being established, and $79 \%$ of the sample has the United States of America as its natural market for export 
destination, followed by Central America (51.6\%), Europe (43.5\%), and South America $(41.6 \%)$

\section{Insert Table 1 about here}

To explore the issue of sample representativeness and non-response bias, differences between early and late respondents were tested (Armstrong and Overton, 1977). Early responses were defined as the first $75 \%$ of returned questionnaires. The last $25 \%$ were considered late respondents and representative of individuals that did not respond to the survey. Early and late respondents were compared for position of respondent (owner, manager or export manager), yearly sales and percentage of export sales on totals and no significant differences were found ( $\mathrm{p}$-value $>0.05$ ), suggesting that non-response bias was not an issue.

In order to avoid any possible problem due to confidentiality of information from the companies, the aggregate and anonymous treatment of data was highlighted at the beginning of the survey. Furthermore, in order to control the "social desirability" bias (Chung and Monroe 2003) it was stressed that there are no correct or incorrect answers to the questions included in the questionnaire. Lastly, and given that a single instrument for gathering information is used in this study, the possible effect of Common Method Variance was examined by means of the Harman test (MacKenzie and Podsakoff 2012). According to this procedure, an analysis is made of whether or not the correlation between variables is significantly influenced by the common source (Chang et al. 2010). In particular, results obtained from an exploratory factor analysis indicate that the items used in the research are not concentrated in a single factor. Consequently, there are no indications of problems derived from Common Method Variance. 


\section{RESULTS}

In order to test the proposed research hypotheses, a PLS-SEM statistical analysis approach is followed, which is particularly suitable for small samples, as is the case in this research and, in general, in studies focused on businesses. According to the approach proposed by Chin (2010), a study is conducted in two stages to analyse and interpret PLS results (Chin 2010): (1) evaluation of external model (measurement), and (2) estimate of inner model (structural).

\subsection{Evaluation of the measurement model}

Results obtained from the estimation of the measurement model support the psychometric properties of the measurement scales (reliability and validity). The reliability of the scales (Table 2) is confirmed given that the coefficients Alpha of Cronbach and of composite reliability (Bagozzi and Yi 1988) are clearly above the minimum values required of 0.7 (Hair et al., 2010). Convergent validity of measuring instruments is also confirmed because, for all constructs, the values of AVE coefficient are above 0.50 and the factor loading of items is above or near 0.7 , which are significant at the level of 0.01 (Table 2).

\section{Insert Table 2 about here}

In turn, this study follows three approaches for evaluating the discriminant validity of the rating scales (Tables 3 and 4). Firstly, it is observed that factor loadings for each 
item in the associated construct are in every case greater than the loads on other latent factors. Furthermore, all factors meet the criterion proposed by Fornell and Larcker (1981), because the square root of each AVE coefficient is larger than the correlations between constructs (Table 3). Lastly, the Heterotrait-Monotrait (HT-MT) values are, in every case, below the threshold of 0.90 (Henseler et al. 2015) (Table 4). These results confirm the discriminant validity of the rating scales used in the empirical research.

\section{Insert Table 3 about here}

\section{Insert Table 4 about here}

\subsection{Evaluation of structural model}

This research follows the three-stage approach proposed by Aldás (2016) for analysing the structural model: (1) coefficient of determination (value $\mathrm{R}^{2}$ ) for latent variables; (2) predictive relevance $\mathrm{Q}^{2}$ (blindfolding), and (3) significance of the structural model path coefficients and effect size (bootstrapping).

This study uses a bootstrap method with 5,000 samples, each of which contains the same number of observations than the original sample (for example, 502 bootstrap cases) to generate standard errors and t values (Chin et al. 1998; Hair et al. 2013). The study makes an estimate of causal relations between latent variables in the model, through the sign and magnitude of path coefficients. The results of the structural model estimate are summarized in Figure 2. In all cases, $R^{2}$ statistics take values above 0.40, which shows that the suggested theoretical model provides a moderate explanation of the variance of dependent variables, in agreement with the reference levels proposed by Chin (1998). Additionally, by using the blindfolding procedure, it is observed that all $\mathrm{Q}^{2}$ 
values are considerable larger than zero, which supports the predictive relevance of the model with regard to dependent variables.

Lastly, the significance of path coefficients of the structural model and the size of effects is compared by means of the bootstrapping procedure. Table 5 summarizes the results obtained for direct relationships in the structural model, including path coefficients, $t$ values, and the level of significance. In this sense, worth mentioning is that, firstly, the empirical evidence obtained supports the factor structure of the second order constructs considered in the study. Thus, it is highlighted that: 1) International Performance is integrated by the dimensions of International Results and Comparative Performance; 2) International Market Orientation is integrated by the dimensions of Customer Orientation, Competitor Orientation, and Inter-functional Coordination; 3) Network Capability is integrated by the dimensions of Coordination, Relational Skills, Partner Knowledge, and Internal Communication; and 4) International Entrepreneurial Orientation is integrated by the dimensions of Innovativeness, Proactiveness, and RiskTaking.

\section{Insert Table 5 about here}

With regard to the research hypotheses, the results obtained (Table 5 and Figure 2) show, firstly, that the International Market Orientation has no statistically significant effect on the International Performance of export SMEs, for which hypothesis H1 is rejected. Conversely, it is confirmed that the Network Capability has a positive influence on the International Performance of the analysed companies (hypothesis H2). Similarly, the empirical evidence obtained supports the significant and positive effect of 
the Entrepreneurial Orientation of SMEs on International Performance (hypothesis H3), Market Orientation (hypothesis H4), and Network Capability (hypothesis H5). In turn, Cohen's $\mathrm{f}^{2}$ for the significant paths in the inner model take values above 0.02 , which suggest satisfactory effects for all endogenous latent factors (Henseler et al. 2009).

\section{Insert Figure 2 about here}

\section{DICUSSION AND CONCLUSIONS}

\subsection{Theoretical implications}

The results obtained in this investigation hold relevant theoretical implications with regard to the internationalization of SMEs and their performance in export markets. Thus, following the proposals of different authors in recent literature on Strategic Management (Deutscher 2016) and internationalization (Knight and Liesch 2016; Pehrsson 2016; Hagen et al. 2017; Paul et al., 2017) this research analyses the joint effect of diverse strategic orientations (International Market Orientation and International Entrepreneurial Orientation) and dynamic capabilities (Network Capability) on the International Performance of SMEs. Particularly, we adopt the “complementary approach" proposed by Hakala (2011) to the study of strategic orientations, focused on the relationships between orientations and the patterns they form. In this sense, the empirical evidence obtained supports that the International Performance of export SMEs is determined by various strategic variables (in this case, strategic orientations and dynamic capabilities), which at the same time are interrelated 
among them. Therefore, beyond the specific explanatory variables studied in this research, its first contribution with regard to previous research is to evidence the need of considering diverse strategic variables and the interrelations existing among them (Hakala, 2011) in order to have a complete perspective of the factors determining the International Performance of SMEs.

Specifically, according to our results, International Performance of export SMEs is positively influenced by Network Capability and their International Entrepreneurial Orientation, although not by their International Market Orientation. Moreover, the findings in this research support the interrelations between the explanatory factors studied, and suggest the existence of an indirect effect of International Entrepreneurial Orientation on International Performance through Network Capability, and even an overlapping in the effect of International Entrepreneurial Orientation and International Market Orientation. Therefore, we find that the combination of specific strategic variables, such as International Entrepreneurial Orientation and Network Capability leads to superior results for export SMEs.

Regarding the direct determinants of International Performance, the results obtained confirm that the capability of SMEs to establish and manage relationships with different partners in the markets where they operate constitutes the primary factor influencing their performance in foreign markets. This result is consistent with the model of Weerawardena et al. (2007), which considers the Network Capability as a determinant factor for the acquisition of knowledge and access to the resources required for internationalization of SMEs. Moreover, the results obtained by Walter et al. (2006), which observe a positive effect of the Network Capability on the International Performance of spin-offs, are confirmed. This result has relevant implications with regard to previous literature, as it supports the theoretical framework proposed by 
Knight and Liesch (2016), which postulates that Network Capability, conceived as a dynamic capability, influences the International Performance of SMEs in combination with strategic orientations.

As for the effect of International Entrepreneurial Orientation, the empirical evidence obtained supports the direct impact of this factor on International Performance, as well as an indirect effect through Network Capability. Thus, the more traditional line of research is supported, which is focused on the positive effect of this variable on the performance of SMEs in foreign markets (Knight 2000; Dimitratos et al. 2004; Hagen et al. 2012; Escandón-Barbosa et al. 2016). Furthermore, the influence of International Entrepreneurial Orientation on the Network Capability is confirmed, which is in agreement with the conceptual model proposed by Weerawardena et al. (2007). This result is especially relevant in terms of contribution to literature, given that prior studies which empirically analyse interrelations between determinant factors of International Performance are scarce (Walter et al. 2006; Zhou et al. 2010), specifically in the scope of SMEs (Knight and Liesch 2016). Therefore, our research meets, at least partially, the need of continue deepening in the interdependence between strategic orientations and other explanatory variables of the Entrepreneurial Performance, as it has been recently pointed out by several authors (Deutscher 2016; Pehrsson 2016).

Finally, worth of special mention are the results obtained in connection with the influence of International Market Orientation on International Performance. In particular, the empirical evidence obtained from our research is in contradiction with the results of several previous studies that have observed a positive impact of Market Orientation on different variables linked to the performance of a company in general (Kirca et al. 2005), and international results in particular (Cadogan et al. 2003, Armario et al. 2008; Chung 2012; Escandón-Barbosa et al. 2016). A possible explanation of this 
phenomenon could be found in the interrelation between International Entrepreneurial Orientation and International Market Orientation, where the influence of the former might cancel the effect of the latter. In this sense, the studies of Cadogan (2003), Armario et al. (2008) and Chung (2012) do not consider Entrepreneurial Orientation as a determinant of International Performance, whereas the research conducted by Escandón-Barbosa et al. (2016) highlights a significant effect of both factors. Consequently, and as has been recently indicated by Deutscher et al. (2016), it appears necessary to deepen the research on the relationship existing between both variables, especially in the international sphere.

Regarding this issue, different authors have suggested the interest of considering alternative "configurations" of strategic orientations, apart from the orthodox approach of analysing the individual direct effect of each of them. Specifically, Deutscher et al. (2016) point out the possibility of aggregating Entrepreneurial Orientation, Market Orientation and Learning Orientation as a higher-order factor influencing firm performance, although only Gnizy et al. (2014) have adopted this approach in the field of Internationalization. From the opposite perspective, Pehrsson (2016, pp. 382) highlight that "it would be valuable to consider Entrepreneurial Orientation and Market Orientation as multidimensional concepts where individual dimensions, or components, may affect performance in different ways". Therefore, our results could be due to the way we have "configured" the strategic orientations on this research.

Another possible explanation for the non-significant effect of International Market Orientation and International Performance may be that Market Orientation could need the intermediation of other variables (e.g. strategy) in order to affect Performance, as suggested by Weerawardena et al. (2007) and Hakala (2011). In this sense, Pehrsson (2016, pp. 382) points out that "market context represents a mechanism that moderates 
direct relationships between Entrepreneurial Orientation and Market Orientation and firm's performance" so "knowledge of markets is essential to Entrepreneurial Orientation and Market Orientation, and both rely on identification of market opportunities to be successful". Thus, according to this author the effect both factors on International Performance of SMEs would be moderated by market context, which could explain the non-significant effect of International Market Orientation on this study.

\subsection{Practical implications}

Results obtained from this study pose interesting implications for foreign trade entrepreneurs and executives, as well as for the management of SMEs' internationalization. From the standpoint of owners and managers, this work evinces the importance of generating a management philosophy and culture within the company, oriented to international entrepreneurship and the establishment of networks with other organizations. Accordingly, it is essential to promote the Proactiveness, Risk-Taking and Innovativeness within the company, encouraging the executives and professionals to actively seek new business opportunities by taking reasonable risks. In this sense, it is very important that SMEs are proactive in making visits abroad and establishing contacts with suppliers or customers in international markets, as a way to anticipate future needs and exploit business opportunities. Likewise, SMEs should foster that decision-makers accept and manage the uncertainty of operating in a foreign market, so that they can be tolerant with regard to the potential risks that international business opportunities offer them. Finally, managers should favour innovativeness, being open to experiment and support new ideas and practices, including the entrance in new markets but also the collaboration with new suppliers and partners. In this sense, property 
leadership, as well as the development of measures for internal dissemination of these values, acquire special importance.

Furthermore, SMEs must develop their capability to establish networks with other relevant organizations and partners, both in the domestic and international markets. This entails the implementation of measures directed to strengthen partner knowledge and their activities, the establishment of smooth communication channels and coordination therewith, the promotion of relational skills of company executives, and favouring internal mechanisms for the dissemination of partner information to all departments. Therefore, the organization's structure and procedures should be oriented to increase the knowledge about the partners (suppliers, intermediaries and strategic allies) and to improve the coordination and interrelations within the network. In this sense, the implementation of communication technologies, both internal (databases, CRMs and intranets) and external (joint platforms and communication tools), is especially important. Although this can be a challenge for SMEs, due to their limitation of resources (human, economic and technological), a smaller size can also be an advantage from the technological perspective, as there are also less people involved in networking so a simpler infrastructure is needed.

As for institutional initiatives intended to favour SMEs' internationalization, these must be directed to promote international entrepreneurship, facilitate the establishment of networks with foreign companies, and eliminate entry barriers in foreign markets. Among the measures that may be developed in this regard, worth mentioning is the simplification of legal and bureaucratic requirements for exporting, the organization and financing of trade missions and fairs that promote the creation of International networks, and the advice from experts in transactions with foreign partners. These incentives must include personalized follow-up, organized by productive sector, and 
should be linked to clear, measurable, attainable and specific objectives, both economical and non-economical, in order to guarantee efficacy of results.

\subsection{Limitations and future lines of research}

This research is not without limitations. To this effect, it is worth to highlight, firstly, the fact that data used are of transversal nature, and it is not possible to know the International Performance of SMEs at different moments in time. Even though this is a common limitation for research of business internationalization, it would be interesting to obtain longitudinal information in future studies so as to allow for the evaluation of the evolution of international results. Regarding the sample used in the empirical research, there could also be some concerns regarding its representativeness. Thus, although we have tested it following the method suggested by Armstrong and Overton (1977), our test relies on just three variables (position of respondent, yearly sales and percentage of export sales on totals), and we cannot warrant total sample representativeness. Another limitation may be the fact that our research is based on surveys to owners and executives of SMEs, which could rise potential problems due to Common Method Variance (MacKenzie and Podsakoff 2012). Even though it is also a common practice in this line of investigation (e.g. Kight and Cavusgil 2004; Armario et al. 2008; Zhang et al. 2009; Escandón-Barbosa et al. 2016), it must be taking into consideration. Consequently, it would be convenient in the future to incorporate objective measurements of variables such as international performance, innovation in the company, or SMEs participation in networks with foreign partners.

Likewise, results obtained in this research also suggest opportunities for developing new lines of study. In this regard, it is worth indicating, firstly, the need for obtaining additional empirical evidence on the interrelation between strategic orientations and 
other explanatory variables of International Performance, as stated previously. Notably, it would be convenient to delve into the relationship existing between International Market Orientation and International Entrepreneurial Orientation and its impact on the results of SMEs in foreign markets. In turn, future research should explore the mediating effect of other variables on the relationship between International Market Orientation and International Performance. Specifically, it can be expected that Market Orientation has a positive impact on International Performance only if it leads the firm to design and implement an appropriate Strategy to approach a foreign market. Therefore, in future research, it would be of special interest to analyse the role of strategy (reflecting actual planning and action of the company) as a mediator influence of strategic orientations and dynamic capabilities on International Performance. Finally, it would be of great interest to develop a cross-cultural study in order to analyse whether the explanatory variables of International Performance for SMEs have any consistent effect in different countries. 


\section{REFERENCES}

Aldás, J. (2016), Modelización estructural con PLS-SEM: Constructos de segundo orden. Madrid: ADD Editorial.

Armario, J.M., Ruiz, D.M., and Armario, E.M. (2009), "Market Orientation and Internationalization in Small and Medium-Sized Enterprises," Journal of Small Business Management, 46(4), 485-511.

Armstrong, J.S., and Overton, T.S. (1977), "Estimating Nonresponse Bias in Mail Surveys, “ Journal of Marketing Research, 14(3), 396-402.

Bagozzi, R.P., and Yi, Y. (1988), "On the evaluation of structural equation models," Journal of the Academy of Marketing Science, 16(1), 74-94.

Barney, J.B. (1991), “Firm resources and sustained competitive advantage,” Journal of Management, 17(1), 99-120.

Bell, J., McNaughton, R., Young, S., and Crick, D. (2003), “Towards an integrative model of small firm internationalization," Journal of International Entrepreneurship, 1(4), 339-362.

Boso, N., Cadogan, J. W., and Story, V. M. (2013), "Entrepreneurial orientation and market orientation as drivers of product innovation success: A study of exporters from a developing economy,” International Small Business Journal, 31(1), 57--81.

Bryson, J.M., Berry, F.S. and Yang, K. (2010), “The State of Public Strategic Management Research: A Selective Literature Review and Set of Future Directions", The American Review of Public Administration, 40(5), 495-521. 
Cadogan, J. W., Cui, C. C., and Li, E. K. Y. (2003), "Export market oriented behavior and export performance: The moderating roles of competitive intensity and technological turbulence," International Marketing Review, 20(5), 493-513.

Cano, C., Carrillat, F., and Jaramillo, F. (2004), “A meta-analysis of the relationship between market orientation and business performance: Evidence from five continents," International Journal of Research in Marketing, 21, 179-200.

Chandler, A.D. (1962), Strategy and structure: Chapters in the history of the industrial enterprise, Cambridge MA: MIT Press.

Chang, S-J., van Witteloostuijn, A., and Eden, L. (2010), "From the Editors: Common method variance in international business research," Journal of International Business Studies, 41, 178-184.

Chetty, S.K., and Holm, D. (2000), "Internationalisation of small to medium-sized manufacturing firms: a network approach," International Business Review, 9(1), 77-93.

Chin, W. W. (1998), “The partial least squares approach to structural equation modelling”, in G. A. Marcoulides (Ed.), Modern methods for business research (pp. 295-336), Mahwah, NJ: Lawrence Erlbaum Associates.

Chin, W. W. (2010), "How to write up and report PLS analyses," in V. E. Vinzi, W. W. Chin, J. Henseler, and H. Wang (Eds.), Handbook of partial least squares: Concepts, methods and applications (pp. 655-690), Berlin Heidelberg: SpringerVerlag.

Chom, N.H. (1991), “The 'alignment' Theory": Creating strategic fit,” Management Decision, 29(1), 20-24. 
Chung, H. F. L. (2012), "Export market orientation, managerial ties, and performance," International Marketing Review, 29(4), 403-423.

Chung, J., and Monroe, G.S. (2003), “Exploring social desirability bias,” Journal of Business Ethics, 44(4), 291-302.

Cohen, W.M., and Levinthal, D.A. (1990), “Absorptive capacity: a new perspective on learning and innovation," Administrative Science Quarterly, 35, 128-152.

Coviello, N.E., and Munro, H.J. (1995), “Growing the Entrepreneurial Firm:

Networking for International Market Development," European Journal of Marketing, 29(7), 49-61.

Covin, J.G., and Miller, D. (2014), "International entrepreneurial orientation:

Conceptual, considerations, research themes, measurement issues, and future research directions," Entrepreneurship Theory and Practice, 38(1), 11-44.

Deutscher, F., Zapkau, F.B., Schwens, C., Baumc, M., and Kabst, R. (2016), "Strategic orientations and performance: A configurational perspective," Journal of Business Research, 69, 849-861.

Dimitratos, P., Lioukas, S. and Carter, S. (2004), “The relationship between entrepreneurship and international performance: The importance of domestic environment," International Business Review, 13(1), 19-41.

Donaldson, L. (2001), The Contingency Theory of Organization, Thousand Oaks: Sage. Douglas, S.P., and Craig, C.S. (2007), "Collaborative and Iterative Translation: An Alternative Approach to Back Translation,” Journal of International Marketing, 15(1), $30-43$. 
Eisenhardt, M. and Martin, J.A. (2000), "Dynamic capabilities: What are they?," Strategic Management Journal, 21(10/11), 1105-1121.

Ellis, P. (2006), "Market orientation and performance: A meta-analysis and crossnational comparisons," Journal of Management Studies, 43, 1089-1107.

Escandón-Barbosa, D., Hernandez-Espallardo, M., and Rodriguez, A. (2016), "International Market Orientation and International Outcomes," Global Economy, 16(4), 669-696.

Ferreira, J.J.M., Fernandes, C.I.. and Ratten, V. (2016), “A co-citation bibliometric analysis of strategic management research", Scientometrics, 109(1), 1-32.

Fornell, C., and Larcker, D. (1981), "Evaluating structural equation models with unobservable variables and measurement error," Journal of Marketing Research, 18, $39-50$.

Freeman, R.E. (1984), Strategic Management: A Stakeholder Approach, Boston: Pitman.

Freeman, S., and Cavusgil, S.T. (2007), “Toward a typology of commitment states among managers of bornglobal firms: A study of accelerated internationalization," Journal of International Marketing, 15(4), 1-40.

Gnizy, I., Baker, W. E., and Grinstein, A. (2014), "Proactive learning culture: A dynamic capability and key success factor for SMEs entering foreign markets," International Marketing Review, 31(5), 477-505.

Gulati, R. (1998), “Alliances and Networks,” Strategic Management Journal, 19, 293 317. 
Hagen, B., Zucchella, A., Cerchiello, P., and De Giovanni, N. (2012), "International strategy and performance Clustering strategic types of SMEs," International Business Review, 21(3), 369-382.

Hagen, B., Zucchella, A., Larimo, J., and Dimitratos, P. (2017), “A Taxonomy of Strategic Postures of International SMEs," European Management Review, doi: 10.1111/emre.12109.

Hair, J.F., Anderson, R.E., Tatham, R.L., and Black, W.C. (2010), Multivariate Data Analysis (7th edition), New Jersey: Prentice Hall.

Hair, J. F., Ringle, C. M., and Sarstedt, M. (2013), "Partial least squares structural equation modeling: Rigorous applications, better results and higher acceptance," Long Range Planning, 46, 1-12.

Hakala, H. (2011), "Strategic Orientations in Management Literature: Three Approaches to Understanding the Interaction between Market, Technology, Entrepreneurial and Learning Orientations," International Journal of Management Reviews, 13, 199-217

Helfat, C. E., and Raubitschek, R. S. (2000), "Product sequencing: Co-evolution of knowledge, capabilities and products," Strategic Management Journal, 21(10/11), 961979.

Henseler, J., Ringle, C. M., and Sarstedt, M. (2015), “A new criterion for assessing discriminant validity in variance-based structural equation modelling," Journal of the Academy of Marketing Science, 43(1), 115-135. 
Henseler, J., Ringle, C.M., and Sinkovics, R.R. (2009), “The use of partial least squares path modelling in international marketing," Advances in International Marketing, 20, 277-319.

Johnsen, A. (2015), "Strategic Management Thinking and Practice in the Public Sector: A Strategic Planning for All Seasons?," Financial Accountability \& Management, 31(3), 243-268.

Jones, M.V., and Coviello, N.E. (2005), "Internationalisation: Conceptualising an entrepreneurial process of behaviour in time," Journal of International Business Studies, 36(3), 284-303.

Keupp, M.M., and Gassmann, O. (2009), “The past and future of international entrepreneurship: A review and suggestions for developing the field," Journal of Management, 36(1), 40-65.

Kirca, A.H., Jayachandra, S., and Bearden, W.O. (2005), "Market orientation: A metaanalytic review and assessment of its antecedents and impact on performance," Journal of Marketing, 69, 24-41.

Knight, G.A. (1997), “Cross-cultural reliability and validity of a scale to measure firm entrepreneurial orientation", Journal of Business Venturing, 12, 213-225.

Knight, G.A. (2000), “Entrepreneurship and marketing strategy: The SME under globalization," Journal of International Marketing, 8(2), 12-32.

Knight, G.A., and Cavusgil, S.T. (2004), "Innovation, organizational capabilities, and the born-global firm," Journal of International Business Studies, 35(2), 124-141. 
Knight, G.A., and Cavusgil, S.T. (2005), "A taxonomy of born-global firms,” Management International Review, 45(3), 15-35.

Knight, G.A., and Liesch , P.W. (2016), "Internationalization: From incremental to born global," Journal of World Business, 51, 93-102

Kohli, A.K., and Jaworski, B.J. (1990), "Market orientation: The construct, research propositions and managerial implications," Journal of Marketing, 54, 1-18.

Laufs, K. and Schwens, C. (2014), "Foreign market entry mode choice of small and medium-sized enterprises: A systematic review and future research agenda," International Business Review, 23(6), 1109-1126.

Laukkanen, T., Nagy, G., Hirvonen, S., Reijonen, H., and Pasanen, M. (2013), “The effect of strategic orientations on business performance in SMEs. A multigroup analysis comparing Hungary and Finland,” International Marketing Review, 30(6), 510-535.

Lumpkin, G.T., and Dess, G.G. (1996), "Clarifying the entrepreneurial orientation construct and linking it to performance," Academy of Management Review, 21(1), 135172.

MacKenzie, S.B., and Podsakoff, P.M. (2012), "Common method bias in marketing: causes, mechanisms, and procedural remedies," Journal of Retailing, 88(4), 542-555.

Marino, L., and George, B.A. 2011), “The Epistemology of Entrepreneurial Orientation: Conceptual Formation, Modeling, and Operationalization," Entrepreneurship: Theory and Practice, 35(5), 989-1024.

Marshall, G.W., Goebel, D.J., and Moncrief, W.C. (2003), "Hiring for success at the buyer-seller interface," Journal of Business Research, 56(4), 247-255. 
McDougall, P., and Oviatt, B. (2000), "International entrepreneurship: the intersection of two research paths," Academy of Management Journal, 43(5), 902-906.

Miller, D. (1983), "The correlates of entrepreneurship in three types of firms," Management Science, 29(7), 770-791.

Mintzberg, H., Ahlstrand, B. and Lampel, J. (2009), Strategy Safari: Your Complete Guide Through the Wilds of Strategic Management (2nd edition), New York: The Free Press.

Moen, O., and Servais, P. (2002), "Born Global or Gradual Global? Examining the Export Behavior of Small and Medium-Sized Enterprises," Journal of International Marketing, 10(3), 49-72.

Mort, G. S., and Weerawardena, J. (2006), "Networking capability and international entrepreneurship: How networks function in Australian born global firms," International Marketing Review, 23(5), 549-572.

Mu, J., Thomas, E., Peng, G., and Di Benedetto, A. (2017), "Strategic orientation and new product development performance: The role of networking capability and networking ability," Industrial Marketing Management, 64, 187-201.

Musteen, M., Datta, D.K., and Butts, M.M. (2014), “Do International Networks and Foreign Market Knowledge Facilitate SME Internationalization? Evidence From the Czech Republic", Entrepreneurship Theory and Practice, 38, 749-774.

Nag, R., Hambrick, D., and Chen, M.-J. (2007), "What is strategic management, really? Inductive derivation of a consensus definition of the field," Strategic Management Journal, 28, 935-955. 
Nerur, S. P., Rasheed, A. A., and Natarajan, V. (2008), "The intellectual structure of the strategic management field: An author co-citation analysis," Strategic Management Journal, 29, 319-336.

Narver, J.C., and Slater, S.F. (1990), “The effect of a market orientation on business profitability," Journal of Marketing, 54(4), 20-35.

Pehrsson, A. (2016), “Firm's strategic orientation, market context, and performance Literature review and opportunities for international strategy research," European Business Review, 28(4), 378-404.

Paul, J., Parthasarathy, S., and Gupta, P. (2017), "Exporting challenges of SMEs: A review and future research agenda," Journal of World Business, 52, 327-342.

Porter, M. E. (1980), Competitive Strategy: Techniques for Analyzing Industries and Competitors, New York: Free Press.

Rialp, A., Rialp, J., and Knight, G.A. (2005), “The phenomenon of early internationalizing firms: what do we know after a decade (1993-2003) of scientific inquiry?," International Business Review, 14(2), 147-166.

Ripollés, M., Blesa, A., and Monferrer, D. (2012), "Factors enhancing the choice of higher resource commitment entry modes in international new ventures," International Business Review, 21(4), 648-666.

Ritter, T., and Gemünden, H.G. (2003), "Network competence: its impact on innovation success and its antecedents," Journal of Business Research, 56(9), 745-755.

Shoham, A., Rose, G., and Kropp, F. (2005), "Market orientation and performance: a meta-analysis," Marketing Intelligence and Planning, 23, 435-454. 
Slater, S., and Narver, J. (1995), "Market orientation and the learning organization," Journal of Marketing, 59(3), 63-75.

Steensma, H.K., Marino, L., and Weaver, K.M. (2000), “Attitudes toward cooperative strategies: A cross-cultural analysis of entrepreneurs," Journal of International Business Studies, 31(4), 591-609

Teece, D. J., Pisano, G., and Shuen, A. (1997), "Dynamic capabilities and strategic management," Strategic Management Journal, 18(7), 509-533.

Teece, D.J. (2014), “The foundations of enterprise performance: Dynamic and ordinary capabilities in an (economic) theory of firms," The Academy of Management Perspectives, 28(4), 328-352.

Torres-Ortega, R., Rialp-Criado, A., Rialp-Criado, J., and Stoian, M.-C. (2015), “How to measure born-global firms' orientation towards international markets?," Revista Española de Investigación de Marketing ESIC, 19, 107-123.

Venkatraman, N. (1989), "Strategic Orientation of Business Enterprises: The Construct, Dimensionality, and Measurement," Management Science, 35(8), 942-962.

Walter, A., Auer, M., and Ritter, T. (2006), “The impact of network capabilities and entrepreneurial orientation on university spin-off performance," Journal of Business Venturing, 21(4), 541-567.

Weerawardena, J., Mort, G., Liesch, P., and Knight, G. (2007), “Conceptualizing accelerated internationalization in the born global firm: A dynamic capabilities perspective," Journal of World Business, 42, 294-306. 
Wernerfelt, B. (1984), “A resource-based view of the firm,”, Strategic Management Journal, 5(2), 171-180.

Yadav, N., Sushil and Sagar, M. (2014), "Revisiting performance measurement and management: deriving linkages with strategic management theories," International Journal of Business Performance Management, 15(2), 87-105.

Zahra, S. A. (2008), "Being entrepreneurial and market driven: Implications for company performance," Journal of Strategy and Management, 1(2), 125-142.

Zahra, S., and D. Garvis (2000), "International Corporate Entrepreneurship and Firm Performance: The Moderating Effect of International Environmental Hostility," Journal of Business Venturing, 15, 469-92.

Zhou, L., Barnes, B.R., and Lu, Y. (2010), “Entrepreneurial proclivity, capability upgrading and performance advantage of newness among international new ventures," Journal of International Business Studies, 41(5), 882-905.

Zollo, M., and Winter, S. (2002), "Deliberate learning and the evolution of dynamic capabilities," Organization Science, 13(3), 339-351. 
Table 1. Sample description

\begin{tabular}{|c|c|c|c|}
\hline Variables & $\%$ & Variables & $\%$ \\
\hline Position of respondent & & Type of products & \\
\hline Owner & 53.4 & Consumer products & 26.1 \\
\hline Manager/Director & 26.1 & Industrial products & 49.7 \\
\hline \multirow[t]{2}{*}{ Exports Manager } & 20.5 & Services & 16.8 \\
\hline & & Other & 7.5 \\
\hline Yearly sales 2015 (Dollars) & & $\%$ Export sales on totals & \\
\hline Less than 1 million & 12.4 & Less than $25 \%$ & 35.4 \\
\hline Between 1 and 5 million & 23.6 & Between $25 \%$ and $50 \%$ & 23.0 \\
\hline Between 5 and 10 million & 23.6 & Between $51 \%$ and $75 \%$ & 18.0 \\
\hline Between 10 and 99 million & 29.8 & More than $75 \%$ & 23.6 \\
\hline More than 99 million & 10.6 & & \\
\hline \multicolumn{2}{|c|}{ Years between establishment and $1^{\text {st }}$ export } & Exporting markets & \\
\hline Less than 3 years & 46.6 & North America & 79.5 \\
\hline Between 3 and 6 years & 17.4 & Central America & 51.6 \\
\hline Between 7 and 10 years & 11.8 & South America & 41.6 \\
\hline Between 11 and 15 years & 13.7 & Europe & 43.5 \\
\hline \multirow[t]{2}{*}{ More than 15 years } & 10.6 & Africa & 12.4 \\
\hline & & Asia & 34.2 \\
\hline
\end{tabular}


Table 2. Measurement Model

\begin{tabular}{|c|c|c|c|c|c|}
\hline Construct & Item & Weights & $\begin{array}{l}\text { Cronbach's } \\
\text { Alpha }\end{array}$ & $\begin{array}{l}\text { Composite } \\
\text { Reliability }\end{array}$ & AVE \\
\hline \multirow{3}{*}{ International Results (IRES) } & IRES1 & 0.93 & \multirow{3}{*}{0.93} & \multirow{3}{*}{0.96} & \multirow{3}{*}{0.88} \\
\hline & IRES2 & 0.94 & & & \\
\hline & IRES3 & 0.94 & & & \\
\hline \multirow{2}{*}{$\begin{array}{l}\text { Comparative Performance } \\
\text { (CPER) }\end{array}$} & CPER1 & 0.96 & \multirow{2}{*}{0.91} & \multirow{2}{*}{0.96} & \multirow{2}{*}{0.91} \\
\hline & CPER2 & 0.96 & & & \\
\hline \multirow{6}{*}{$\begin{array}{l}\text { Customer Orientation } \\
\text { (CUSO) }\end{array}$} & CUSO1 & 0.85 & \multirow{6}{*}{0.93} & \multirow{6}{*}{0.95} & \multirow{6}{*}{0.75} \\
\hline & CUSO2 & 0.93 & & & \\
\hline & CUSO3 & 0.89 & & & \\
\hline & CUSO4 & 0.87 & & & \\
\hline & CUSO5 & 0.86 & & & \\
\hline & CUSO6 & 0.82 & & & \\
\hline \multirow{4}{*}{$\begin{array}{l}\text { Competitor Orientation } \\
(\mathrm{COMO})\end{array}$} & COMO1 & 0.84 & \multirow{4}{*}{0.90} & \multirow{4}{*}{0.93} & \multirow{4}{*}{0.76} \\
\hline & $\mathrm{COMO} 2$ & 0.91 & & & \\
\hline & COMO3 & 0.90 & & & \\
\hline & COMO4 & 0.84 & & & \\
\hline \multirow{5}{*}{$\begin{array}{l}\text { Inter-functional Coordination } \\
\text { (INTC) }\end{array}$} & INTC1 & 0.85 & \multirow{5}{*}{0.92} & \multirow{5}{*}{0.94} & \multirow{5}{*}{0.75} \\
\hline & INTC2 & 0.85 & & & \\
\hline & INTC3 & 0.90 & & & \\
\hline & INTC4 & 0.87 & & & \\
\hline & INTC5 & 0.86 & & & \\
\hline \multirow{6}{*}{ Coordination (COOR) } & COOR1 & 0.90 & \multirow{6}{*}{0.95} & \multirow{6}{*}{0.96} & \multirow{6}{*}{0.82} \\
\hline & COOR2 & 0.92 & & & \\
\hline & COOR3 & 0.92 & & & \\
\hline & COOR4 & 0.91 & & & \\
\hline & COOR5 & 0.87 & & & \\
\hline & COOR6 & 0.89 & & & \\
\hline \multirow{4}{*}{ Relational Skills (RELS) } & RELS1 & 0.92 & \multirow{4}{*}{0.95} & \multirow{4}{*}{0.97} & \multirow{4}{*}{0.87} \\
\hline & RELS2 & 0.94 & & & \\
\hline & RELS3 & 0.94 & & & \\
\hline & RELS4 & 0.94 & & & \\
\hline & PARK1 & 0.93 & & & \\
\hline$D$ & PARK2 & 0.95 & 000 & 006 & 006 \\
\hline 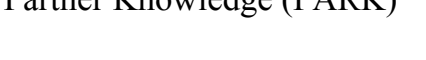 & PARK3 & 0.93 & 0.93 & 0.90 & 0.00 \\
\hline & PARK4 & 0.90 & & & \\
\hline Internal Communication & ICOM1 & 0.88 & 01 & 003 & 073 \\
\hline (ICOM) & ICOM2 & 0.76 & 0.91 & 0.73 & 0.13 \\
\hline
\end{tabular}




\begin{tabular}{llllll}
\hline & ICOM3 & 0.91 & & & \\
& ICOM4 & 0.92 & & & \\
& ICOM5 & 0.81 & & & \\
& INNO1 & 0.88 & & 0.93 & 0.72 \\
Innovativeness (INNO) & INNO2 & 0.89 & & & \\
& INNO3 & 0.77 & 0.90 & & \\
& INNO4 & 0.88 & & 0.77 \\
Proactiveness (PROA) & INNO5 & 0.82 & & & \\
& PROA1 & 0.84 & & & \\
& PROA2 & 0.85 & & & \\
& PROA3 & 0.91 & 0.93 & & \\
& PROA4 & 0.89 & & & \\
& PROA5 & 0.90 & & & \\
\hline
\end{tabular}


Table 3. Analysis of discriminant validity for the procedure proposed by Fornell and Larker (1981)

\begin{tabular}{|c|c|c|c|c|c|c|c|c|c|c|c|c|}
\hline & $\begin{array}{l}\text { International } \\
\text { Results }\end{array}$ & $\begin{array}{l}\text { Comparative } \\
\text { Performance }\end{array}$ & $\begin{array}{c}\text { Customer } \\
\text { Orientation }\end{array}$ & $\begin{array}{l}\text { Competitor } \\
\text { Orientation } \\
\end{array}$ & \begin{tabular}{|c|} 
Inter-functional \\
Coordination \\
\end{tabular} & Coordination & $\begin{array}{c}\text { Relational } \\
\text { Skills }\end{array}$ & $\begin{array}{c}\text { Partner } \\
\text { Knowledge }\end{array}$ & \begin{tabular}{|c|} 
Internal \\
Communication
\end{tabular} & Innovativeness & Proactiveness & Risk-Taking \\
\hline $\begin{array}{c}\text { International } \\
\text { Results }\end{array}$ & $0.936^{\mathrm{a}}$ & & & & & & & & & & & \\
\hline $\begin{array}{l}\text { Comparative } \\
\text { Performance } \\
\end{array}$ & 0.744 & 0.956 & & & & & & & & & & \\
\hline $\begin{array}{c}\text { Customer } \\
\text { Orientation } \\
\end{array}$ & 0.305 & 0.261 & 0.868 & & & & & & & & & \\
\hline $\begin{array}{l}\text { Competitor } \\
\text { Orientation } \\
\end{array}$ & 0.418 & 0.331 & 0.782 & 0.873 & & & & & & & & \\
\hline $\begin{array}{l}\text { Inter-functional } \\
\text { Coordination }\end{array}$ & 0.358 & 0.294 & 0.720 & 0.726 & 0.866 & & & & & & & \\
\hline Coordination & 0.504 & 0.396 & 0.599 & 0.641 & 0.684 & 0.903 & & & & & & \\
\hline $\begin{array}{c}\text { Relational } \\
\text { Skills }\end{array}$ & 0.436 & 0.331 & 0.550 & 0.559 & 0.686 & 0.834 & 0.935 & & & & & \\
\hline $\begin{array}{c}\text { Partner } \\
\text { Knowledge }\end{array}$ & 0.450 & 0.352 & 0.553 & 0.610 & 0.659 & 0.814 & 0.837 & 0.927 & & & & \\
\hline $\begin{array}{c}\text { Internal } \\
\text { Communication } \\
\end{array}$ & 0.459 & 0.405 & 0.612 & 0.608 & 0.693 & 0.828 & 0.783 & 0.728 & 0.857 & & & \\
\hline Innovativeness & 0.356 & 0.331 & 0.597 & 0.560 & 0.594 & 0.508 & 0.517 & 0.504 & 0.418 & 0.848 & & \\
\hline Proactiveness & 0.389 & 0.340 & 0.672 & 0.648 & 0.590 & 0.555 & 0.482 & 0.494 & 0.469 & 0.764 & 0.880 & \\
\hline Risk-Taking & 0.467 & 0.443 & 0.676 & 0.662 & 0.637 & 0.561 & 0.513 & 0.540 & 0.541 & 0.805 & 0.807 & 0.888 \\
\hline
\end{tabular}

${ }^{\text {a }}$ Square root of AVE coefficient of the construct 
Table 4. Analysis of Heterotrait-Monotrait (HT-MT) discriminant validity

\begin{tabular}{|c|c|c|c|c|c|c|c|c|c|c|c|}
\hline & $\begin{array}{l}\text { International } \\
\text { Results }\end{array}$ & $\begin{array}{l}\text { Comparative } \\
\text { Performance }\end{array}$ & $\begin{array}{l}\text { Customer } \\
\text { Orientation }\end{array}$ & $\begin{array}{l}\text { Competitor } \\
\text { Orientation }\end{array}$ & $\begin{array}{c}\text { Inter-functional } \\
\text { Coordination }\end{array}$ & Coordination & $\begin{array}{l}\text { Relational } \\
\text { Skills }\end{array}$ & $\begin{array}{c}\text { Partner } \\
\text { Knowledge }\end{array}$ & \begin{tabular}{|c|} 
Internal \\
Communication
\end{tabular} & Innovativeness & Proactiveness \\
\hline $\begin{array}{l}\text { Comparative } \\
\text { Performance }\end{array}$ & 0.811 & & & & & & & & & & \\
\hline $\begin{array}{c}\text { Customer } \\
\text { Orientation }\end{array}$ & 0.326 & 0.283 & & & & & & & & & \\
\hline $\begin{array}{l}\text { Competitor } \\
\text { Orientation }\end{array}$ & 0.458 & 0.365 & 0.853 & & & & & & & & \\
\hline $\begin{array}{c}\text { Inter-functional } \\
\text { Coordination }\end{array}$ & 0.385 & 0.321 & 0.775 & 0.800 & & & & & & & \\
\hline Coordination & 0.537 & 0.426 & 0.634 & 0.695 & 0.729 & & & & & & \\
\hline Relational Skills & 0.464 & 0.357 & 0.583 & 0.606 & 0.733 & 0.875 & & & & & \\
\hline $\begin{array}{c}\text { Partner } \\
\text { Knowledge }\end{array}$ & 0.481 & 0.381 & 0.588 & 0.666 & 0.705 & 0.856 & 0.882 & & & & \\
\hline $\begin{array}{c}\text { Internal } \\
\text { Communication } \\
\end{array}$ & 0.494 & 0.441 & 0.661 & 0.672 & 0.752 & 0.880 & 0.837 & 0.781 & & & \\
\hline Innovativeness & 0.391 & 0.367 & 0.647 & 0.623 & 0.651 & 0.545 & 0.556 & 0.544 & 0.456 & & \\
\hline Proactiveness & 0.416 & 0.371 & 0.720 & 0.709 & 0.633 & 0.585 & 0.508 & 0.522 & 0.509 & 0.828 & \\
\hline Risk-Taking & 0.507 & 0.488 & 0.732 & 0.731 & 0.693 & 0.601 & 0.551 & 0.583 & 0.594 & 0.886 & 0.876 \\
\hline
\end{tabular}


Table 5. Structural Model

\begin{tabular}{lcc}
\hline & Coefficient & T-Student \\
\hline Second order factors & & \\
\hline International Performance $\rightarrow$ International Results & 0.96 & $147.85^{* *}$ \\
International Performance $\rightarrow$ Comparative Performance & 0.91 & $54.28^{* *}$ \\
Market Orientation $\rightarrow$ Customer Orientation & 0.93 & $53.13^{* *}$ \\
Market Orientation $\rightarrow$ Competitor Orientation & 0.90 & $44.46^{* *}$ \\
Market Orientation $\rightarrow$ Inter-functional Coordination & 0.89 & $32.21^{* *}$ \\
Network Capability $\rightarrow$ Coordination & 0.95 & $114.46^{* *}$ \\
Network Capability $\rightarrow$ Relational Skills & 0.93 & $58.67^{* *}$ \\
Network Capability $\rightarrow$ Partner Knowledge & 0.91 & $46.84^{* *}$ \\
Network Capability $\rightarrow$ Internal Communication & 0.90 & $41.56^{* *}$ \\
Entrepreneurial Orientation $\rightarrow$ Innovativeness & 0.92 & $43.30^{* *}$ \\
Entrepreneurial Orientation $\rightarrow$ Proactiveness & 0.93 & $81.51^{* *}$ \\
Entrepreneurial Orientation $\rightarrow$ Risk-Taking & 0.93 & $69.28^{* *}$ \\
\hline Causal relations & & \\
\hline H1: Market Orientation $\rightarrow$ International Performance & -0.16 & $1.02(\mathrm{n} . \mathrm{s})$ \\
H2: Network Capability $\rightarrow$ International Performance & 0.43 & $3.18^{* *}$ \\
H3: Entrepreneurial Orientation $\rightarrow$ International Performance & 0.32 & $2.74^{* *}$ \\
H4: Entrepreneurial Orientation $\rightarrow$ Market Orientation & 0.74 & $15.98^{* *}$ \\
H5: Entrepreneurial Orientation $\rightarrow$ Network Capability & 0.60 & $6.85^{* *}$ \\
\hline$*$ \& &
\end{tabular}
$* \mathrm{p}<0.05 ; *{ }^{*} \mathrm{p}<0.01$, n.s. $=$ not significant 
Figure 1. Research Model

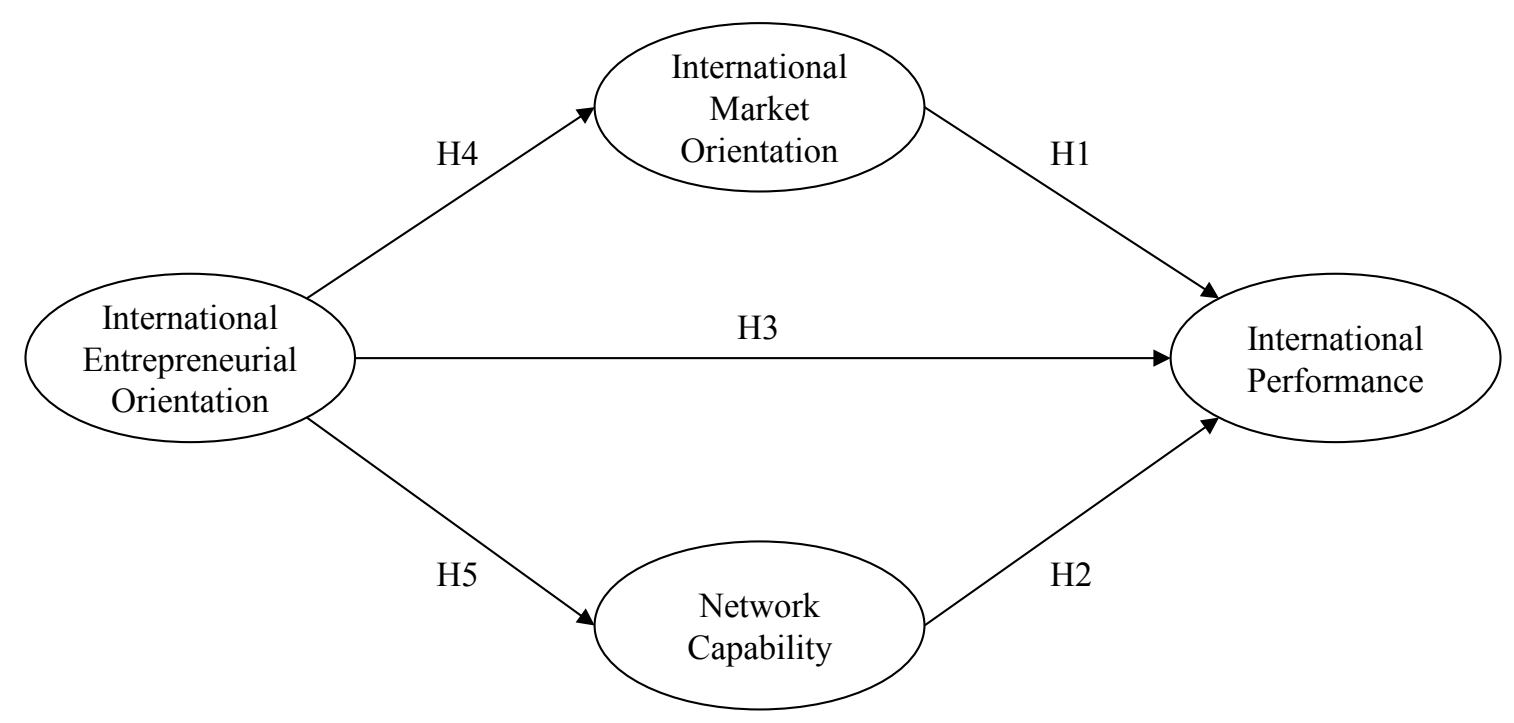


Figure 2. Results from the Structural Model

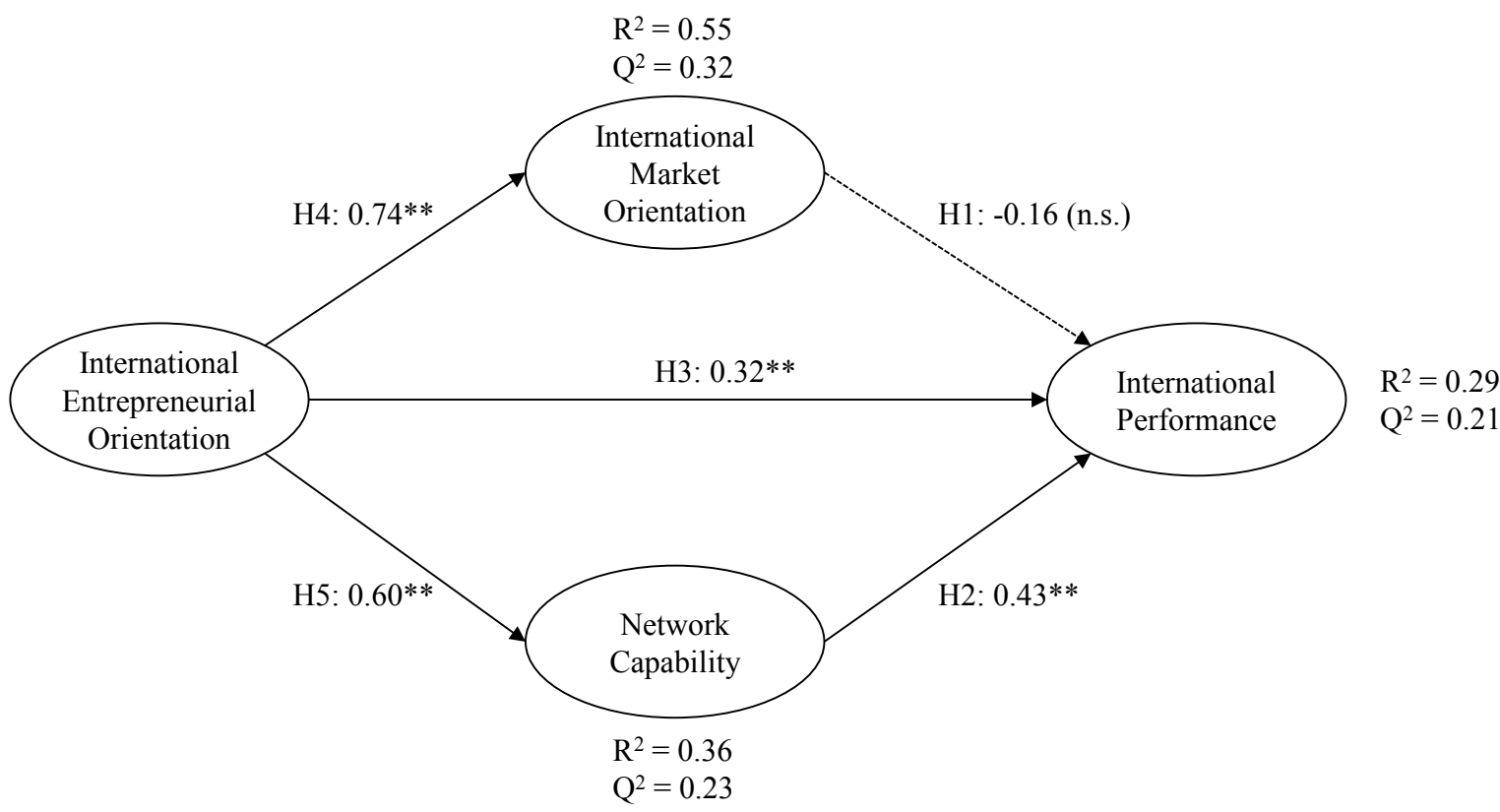

${ }^{*} \mathrm{p}<0.05 ; *{ }^{*} \mathrm{p}<0.01$, n.s. $=$ not significant. 


\section{APPENDIX}

\begin{tabular}{|c|c|}
\hline \multicolumn{2}{|c|}{ International results (IRES). Source: Knight and Cavusgil (2004) } \\
\hline IRES1 & Percentage of participation in the international market \\
\hline IRES2 & Sale growth in the international market \\
\hline IRES3 & Profits before taxes in the international market \\
\hline \multicolumn{2}{|c|}{ Comparative performance (CPER). Source: Knight and Cavusgil (2004) } \\
\hline CPER1 & Sale growth in the main export market, as compared to the main competitors \\
\hline CPER2 & Investment return in the main export market, as compared to the domestic market \\
\hline \multicolumn{2}{|c|}{ Innovativeness (INNO). Source: Zhou et al. (2010) } \\
\hline INNO1 & Our executives always promote ideas of new products for international markets \\
\hline INNO2 & $\begin{array}{l}\text { Our executives are very open with regard to innovative forms in order to exploit } \\
\text { opportunities in international markets }\end{array}$ \\
\hline INNO3 & $\begin{array}{l}\text { Our executives believe that an opportunity in the international markets is greater than one } \\
\text { in the domestic markets }\end{array}$ \\
\hline INNO4 & Our executives continually seek new export markets \\
\hline INNO5 & Our executives are willing to consider new suppliers/customers abroad \\
\hline \multicolumn{2}{|c|}{ Proactiveness (PROA). Source: Zhou et al. (2010) } \\
\hline PROA1 & Our executives have attended national or international trade fairs regularly \\
\hline PROA2 & Our executives have spent some time visiting abroad \\
\hline PROA3 & $\begin{array}{l}\text { Our executives actively seek the contact with suppliers or customers in the international } \\
\text { markets }\end{array}$ \\
\hline PROA4 & Our executives regularly monitor the tendencies in the export markets \\
\hline PROA5 & Our executives actively explore business opportunities abroad \\
\hline \multicolumn{2}{|c|}{ Risk-Taking (RISK). Source: Zhou et al. (2010) } \\
\hline RISK1 & Our executives are more focused on opportunities than on risks abroad \\
\hline RISK2 & $\begin{array}{l}\text { When we face decisions regarding exports or other international transactions, our } \\
\text { executives are always tolerant to potential risks }\end{array}$ \\
\hline RISK3 & Our executives have a shared vision with regard to foreign market risks \\
\hline RISK4 & Our executives evaluate the opportunities that entail some risk abroad \\
\hline \multicolumn{2}{|c|}{ Customer Orientation (CUSO). Source: Narver and Slater (1990) } \\
\hline CUSO1 & The objectives of our company are focused mainly on customer satisfaction \\
\hline CUSO2 & We constantly monitor our level of commitment to the customer's needs \\
\hline CUSO3 & Our strategy is based on the understanding of the customer's needs \\
\hline CUSO4 & $\begin{array}{l}\text { Our business strategies are driven by our beliefs on how may we create greater value for the } \\
\text { customer }\end{array}$ \\
\hline CUSO5 & We measure customer satisfaction frequently and systematically \\
\hline CUSO6 & We pay special attention to post-sale service \\
\hline \multicolumn{2}{|c|}{ Competitor Orientation (COMO). Source: Narver and Slater (1990) } \\
\hline COMO1 & $\begin{array}{l}\text { Our sales staff frequently shares information within the company in connection with the } \\
\text { strategies of competitors }\end{array}$ \\
\hline
\end{tabular}




\begin{tabular}{|c|c|}
\hline $\mathrm{COMO} 2$ & We swiftly respond to competitor actions \\
\hline $\mathrm{COMO} 3$ & Our executives regularly analyse the strategies and strengths of our competitors \\
\hline $\mathrm{COMO} 4$ & We focus on customers with whom we have an opportunity of competitive advantage \\
\hline \multicolumn{2}{|c|}{ Inter-functional coordination (INTC). Source: Narver and Slater (1990) } \\
\hline INTC1 & Our executives regularly visit our current and potential customers \\
\hline INTC2 & $\begin{array}{l}\text { We openly share information about our successful and unsuccessful experiences with } \\
\text { customers throughout all functions within the company }\end{array}$ \\
\hline INTC3 & All of our functional areas are integrated to meet the needs of our target markets \\
\hline INTC4 & $\begin{array}{l}\text { All of our managers understand the way in which each can contribute to the creation of value } \\
\text { for the customer }\end{array}$ \\
\hline INTC5 & We share resources throughout the entire company \\
\hline \multicolumn{2}{|c|}{ Coordination (COOR). Source: Ritter and Gemünden (2003) and Walter et al. (2006) } \\
\hline COOR1 & We analyse what we would like and wish to achieve with each partner \\
\hline COOR2 & We adjust the use of resources (for example, staff, finance) for each relation with partners \\
\hline COOR3 & We learn about the goals, capacities, and strategies of our partners \\
\hline COOR4 & We perform early evaluations of likely partners in order to plan for the building of relations \\
\hline COOR5 & We designate coordinators whom will be responsible for the relation with our partners \\
\hline COOR6 & $\begin{array}{l}\text { We regularly discuss the way in which we can mutually support our successes with our } \\
\text { partners }\end{array}$ \\
\hline \multicolumn{2}{|c|}{ Relational skills (RELS). Source: Ritter and Gemünden (2003) and Walter et al. (2006) } \\
\hline RELS1 & We have the capability to build good personal relations with business partners \\
\hline RELS2 & We are able to step on our partners shoes \\
\hline RELS3 & We can negotiate flexibly with our partners \\
\hline RELS4 & Nearly always we solve problems with our partners in a constructive way \\
\hline \multicolumn{2}{|c|}{ Partner knowledge (PARK). Source: Ritter and Gemünden (2003) and Walter et al. (2006) } \\
\hline PARK1 & We know the markets of our partners \\
\hline PARK2 & We know the products/processes/services of our partners \\
\hline PARK3 & We know the strengths and weaknesses of our partners \\
\hline PARK4 & We know the capabilities and strategies of our competitors \\
\hline \multicolumn{2}{|r|}{ Internal communication (ICOM). Source: Ritter and Gemünden (2003) and Walter et al. (2006) } \\
\hline ICOM1 & In our organization, we hold regular meetings for each project \\
\hline ICOM2 & In our organization, employees develop informal contact among themselves \\
\hline ICOM3 & In our organization, communication is regularly made through projects and subject areas \\
\hline ICOM4 & In our organization, managers and employees use systematic feedback \\
\hline ICOM5 & In our organization, information is regularly exchanged in a spontaneous fashion \\
\hline
\end{tabular}

